\title{
Biochemical transmutation in Lumbricus terrestris and phytoextraction of heavy metals from the swamp of Challawa industrial layout, Kano, Nigeria
}

\author{
R. O. Arise ${ }^{1}$ (I) D. I. Basiru' ${ }^{1} \cdot$ O. Olufemi ${ }^{1} \cdot$ R. I. Adeoye ${ }^{1}$
}

Received: 1 November 2020 / Accepted: 9 February 2021 / Published online: 23 February 2021

(c) The Author(s) 2021 OPEN

\begin{abstract}
Discharge of untreated industrial effluents has been associated with soil contamination. Biochemical alterations in Lumbricus terrestris and remediation capacity of Azadirachta indica tree from industrial effluent discharge locations in Challawa $(A$ and $B)$ and Kura village (control location $C$ ) were assessed. Levels of nitrate, phosphate, iron, chloride, and hardness at locations $A$ and $B$ were significantly $(p<0.05)$ higher than those at location $C$, but their sulfate concentrations were significantly $(p<0.05)$ weaker. $\mathrm{pH}$ and magnesium concentration at location $\mathrm{A}$ were significantly higher than those at locations $\mathrm{B}$ and $\mathrm{C}$. Levels of $\mathrm{Fe}, \mathrm{Cu}, \mathrm{Zn}, \mathrm{Pb}$ and $\mathrm{Mn}$ in soils at the discharge locations were significantly $(p<0.05)$ higher than those of C. Azadirachta indica tree (AIT) had a translocation factor (TF) $>1$ for $\mathrm{Pb}$ and $\mathrm{Zn}$, while its biological concentration factor (BCF) was $>1$ for Fe. Values of biological accumulation coefficient (BAC) for AIT and soil contamination factor (CF) were $<1$ for the metals. Bioindicators of oxidative stress (MDA, GST, CAT and SOD) in earthworm supernatants from the discharge locations were significantly higher $(p<0.05)$ compared to that at location $C$, while their GSH levels were significantly $(p<0.05)$ lower. Acetylcholinesterase (AChE) activity in earthworm supernatants from discharge locations was significantly lower $(p<0.05)$ in comparison with the control. Trends in results revealed that AIT may be useful for extraction and stabilization of heavy metals in polluted soils. Also, the biochemical alterations in L. terrestris may serve as sensitive bioindicators of soil contamination.
\end{abstract}

Keywords Lumbricus terrestris · Effluent discharge $\cdot$ Phytoremediation capacity $\cdot$ Azadirachta indica tree $\cdot$ Soil contamination

\section{Introduction}

Inadequate management of large quantity of wastes generated through various anthropogenic activities is a growing and critical problem in developing countries $[27,55]$. Inappropriate discharge of industrial wastes has been a major concern for most governments and industrialists. The discharge of effluents in most instances does not always meet the pretreatment requirements, hence leading to increasing environmental pollution and the attending health hazards [56]. When toxic waste such as insecticides, heavy metals, ammonia, aromatic hydrocarbons and organic contaminants is improperly disposed, they accumulate mostly in groundwater, surface water and plants with deleterious effects on plants, humans and ecosystem $[3,67]$. These wastes are extremely toxic even at minute concentrations. More so, most of them are non-degradable in nature and can persist in the environment thereby leading to bioaccumulation and biomagnification [7]. Ingestion of food contaminated with heavy metal has been reported to significantly deplete some essential nutrients in humans leading to malnutrition,

R. O. Arise, arise.ro@unilorin.edu.ng; D. I. Basiru, abusofiyyah@yahoo.com; O. Olufemi, olufemiolalekan81@gmail.com; R. I. Adeoye, adeoye.ri@unilorin.edu.ng | ${ }^{1}$ Faculty of Life Sciences, Department of Biochemistry, University of Ilorin, Ilorin, Nigeria. 
reduced immunological defenses, damage DNA and vital organs and increased rates of gastrointestinal cancer [22, $36,69]$. The severity of health outcome from either acute or chronic exposure to heavy metals is dependent on the form and type of metal, means and extent of exposure, and individual susceptibility [37].

Phytoremediation is a natural mechanism whereby are utilized to clean-up, degrade and stabilize contaminants in polluted soils and water in order to improve their quality $[57,70]$. The uptake mechanisms of heavy metal by plants include phytovolatilization, phytoextraction, phytostabilization, phytoaccumulation and rhizofiltration, [65]. Remediating soils polluted by heavy metals has been challenging due to their non-biodegradable nature. The traditional strategies employed for removing heavy metal in soil include soil washing, soil incineration, excavation and landfill and application of electric field $[21,63]$. These physicochemical remediation strategies are not cost effective and are inefficient at low contaminants concentration $[5,21]$. Furthermore, these approaches can permanently alter the biochemical properties of the soil thereby leading to the degradation of soil components and consequently introducing secondary pollutants [4]. The development of new remediation technologies is therefore necessary for efficient and cost-effective reclamation of heavy metal-contaminated soil. Neem plant (Azadirachta indica) belongs to the Meliaceae family, they are abundant in tropical regions of the world. Azadirachta indica trees grow to height of about $20-23 \mathrm{~m}$ and the diameter of its trunk is around 4-5 ft [31]. It has been used extensively for the treatment of many ailments due to the presence of various bioactive compounds in its parts [6]. Azadirachta indica has also been recommended as a potentially useful plant for remediating soil [1].

Biochemical and cellular responses of some organisms inhabiting contaminated soil have become important biological tools for quality assessment of soil ecosystem. [40]. Soil invertebrate such as Lumbricus terrestris (earthworm) offers substantive targets due to the essential role they play in organic matter decomposition, enhancement of soil structure and fertility. Terrestrial invertebrates are good biomarker of soil contaminants due to their direct contact with soil water or nutrients, unlike several vertebrates that have indirect exposure through food chain [40]. They are considerably affected by pollutants originating from agricultural processes such as excessive use of biocides, atmospheric deposition and industrial activities because of their direct interactions with soil. Earthworm has been shown to be a valuable soil pollution bioindicator [45].

Kano is a booming industrial center in Nigeria with many industrial establishments comprising of chemical industries, tanneries, textiles, and food processing factories which discharge waste waters into rivers and vegetation consequently causing the deterioration of water quality of Challawa River, one of the receiving rivers of the pollutants [14]. This research work therefore explored the use of earthworm as a novel biochemical marker of the effects of soil pollutants from industrial effluents as well as the efficiency of neem plant as phytoremediator in the swamp around Challawa industrial layout, Kano.

\section{Materials and methods}

\subsection{Sampling locations}

This research work was done in Challawa industrial estate, Kumbotso LGA, Kano State, Northern Nigeria. The major industries located in the experimental area include tannery, textiles, and food processing/packaging factories. Three study locations/sites were designated as A, B and $C$. Site $C$ (control location) is in Kura village, where there is no industrial activities and discharge of effluents. More so, Kura has Kharif irrigation that supplies clean water to the plants. Plants and soil around site C (Kura) were subjected to less pollution compared to the experimental/sampling sites; hence, this qualifies site $C$ the control. Location $A$ referred to Fankudu-Gabas land area within 5-20 m of the canal, while location $B$ is the Fakudu-Yamma land area within 5-20 m of the point of discharge into the River from the canal (Fig. 1). The effluents from these two locations are mainly from textile and tannery industries.

\subsection{Collection of soil samples}

Soil was obtained from the sampling locations (A, B and C). All containers were washed and dried before collection of samples. Samples of soil were collected in triplicate from each location. Top soils $(0-20 \mathrm{~cm}$ depth) from the rhizosphere were obtained from where plant samples were uprooted. Soil samples were collected into appropriately labeled containers and transported immediately to the laboratory for analyses. The lumps and crumbs of each soil sample were removed after air drying, thereafter the soil samples were passed through $2 \mathrm{~mm}$ mesh in order to eliminate coarse particles before sub-sampling for physicochemical analysis.

\subsection{Collection of plant samples}

A whole plant of dominant plant species was uprooted from each sampling location. The plant samples obtained were authenticated at the herbarium section of Department of Biological Science, Bayero University Kano. Twelve plant samples were randomly taken from each location 


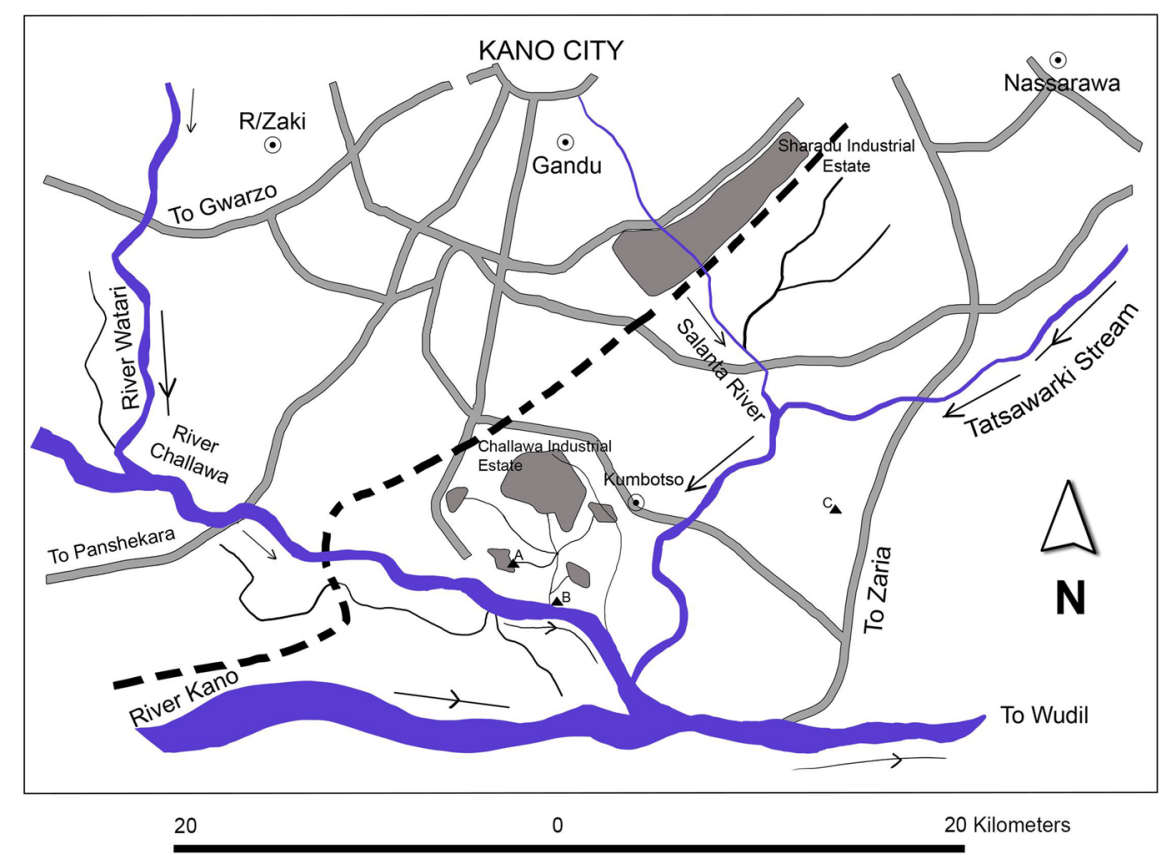

MAP OF CHALLAWA RIVER SHOWING THE SAMPLING POINTS

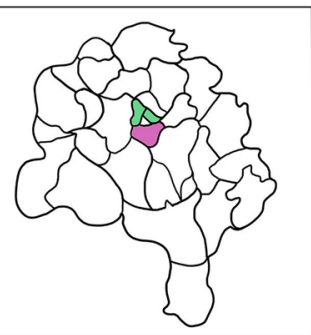

Kano state showing the study area
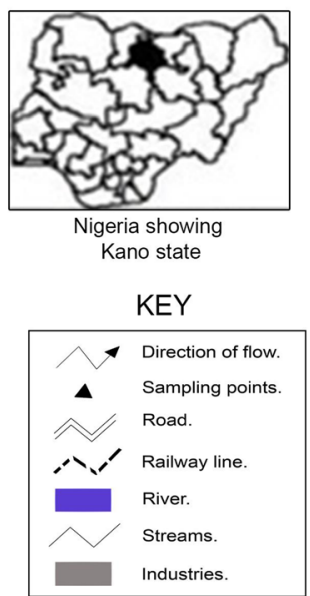

Fig. 1 Map of Challawa River showing the sampling locations

and were placed in clean well-labeled nylon bags, and transported to the laboratory for analyses.

\subsection{Method of collection, homogenization and fractionation of Lumbricus terrestris}

20 earthworm samples were randomly taken from each of the locations and were kept in clean and dried bottles at $0{ }^{\circ} \mathrm{C}$. The earthworms were kept in the bottle with the designated label and thereafter kept in a freezer. Frozen samples of the earthworms were thawed on ice and subsequently homogenized in $0.02 \mathrm{M}$ phosphate buffer, $\mathrm{pH}$ 7.5 and subsequently centrifuged at $4000 \mathrm{rpm}$ at $25^{\circ} \mathrm{C}$ for $20 \mathrm{~min}$. The supernatant obtained was used for analysis.

\subsection{Determination of physicochemical parameters of soil samples}

The method described by Association of Official Analytical Chemists [8] was used to analyze the minerals in the soil samples from locations $A, B$ and $C$. The soil samples were placed in the oven at $550^{\circ} \mathrm{C}$, the ash obtained was thereafter heated in $10 \mathrm{ml} \mathrm{HCl}(20 \% \mathrm{v} / \mathrm{v})$ and then filtered into a volumetric flask, deionized water was added to the filtrate to make it up to $100 \mathrm{ml}$ mark. Sulfate, nitrate, phosphate and chloride were determined spectrophotometrically using UV/Vis Spectrophotometer model $752 \mathrm{~N}$.

\subsection{Determination of heavy metals levels in soil samples}

Atomic Absorption Spectrophotometer (AAS Model Bulk Scientific Accuzy 211) was used to determine the concentrations of iron, copper, zinc, lead, cobalt, chromium and manganese ions in $0.5 \mathrm{~g}$ of air-dried ground soil sample according to the AOAC [8] method. All values were expressed in ppm.

\subsection{Determination of heavy metals levels in whole Azadirachta indica plant}

The whole plant (roots, leaves and stem) were collected and weighed to determine their wet mass, thereafter they were oven dried at $80^{\circ} \mathrm{C}$ for $48 \mathrm{~h}$. The dried samples were ground and the concentration of iron, copper, zinc, lead, cobalt, chromium and manganese ions in the resulting powders were analyzed according to AOAC [8] method. 


\subsection{Determination of phytoremediation quotient}

The translocation factor (TF) or shoot-root quotient is used to measure the potential of a plant to transfer heavy metals from the roots through shoots and leaves of a plant, which is mainly responsible for phytoextraction [9].

$\mathrm{TF}=[\text { Metals }]_{\text {shoot }} /[\text { Metal }]_{\text {root }}$

where [Metals] means concentration of the heavy metal.

The biological concentration factor (BCF) is the proportion of metal concentration in the roots of a plant to the soil concentration of that metal [62]:

$\mathrm{BCF}=[\text { Metal }]_{\mathrm{root}} /[\text { Metal }]_{\text {soil }}$

Biological accumulation coefficient (BAC) is the ratio of heavy metal levels in shoots to that in the soil [74]:

$\mathrm{BAC}=[\text { Metal }]_{\text {shoot }} /[\text { Metal }]_{\text {soil }}$

Contamination factor (CF) is the ratio of the concentration of metal in the study $\left(C_{s}\right)$ samples to the baseline concentration $\left(C_{\mathrm{b}}\right)[61]$ :

$\mathrm{CF}=\left[C_{\mathrm{s}}\right] /\left[C_{\mathrm{b}}\right]$

\subsection{Determination of biochemical parameters}

The total amount of protein in the supernatant of the earthworm was determined by using the method of Gornal et al. [32]. Malondialdehyde (MDA) levels in the supernatant was determined by Buege and Aust [18] method. Glutathione-S-transferase activity and the concentration reduced glutathione were evaluated using the methods of Habig et al. [33] and Ellman [23], respectively. Catalase in supernatant was evaluated using the method of Kaplan and Grooves [41]. Superoxide dismutase was determined by the method of Misra and Fridovich [52]. Acetylcholinesterase activity was evaluated according to the method of Ellman et al. [24].

\subsubsection{Statistical analysis}

The data generated are presented as mean \pm SD of triplicate determinations except otherwise stated. Significance difference was evaluated using one-way ANOVA, the group means was compared by Tukey's test. Values were considered significantly different at $p<0.05$. All statistical analyses were performed using SPSS for windows version 20 (SPSS, Inc., Chicago, USA).

\section{Results}

The physicochemical properties of the soil samples from sites A, B and C are shown in Table 1. The levels of nitrate, phosphate, iron, chloride and hardness of soil samples obtained from sites A and B were significantly $(p<0.05)$ higher than the control site $C$. In contrast, sulfate concentrations of soil samples obtained from sites A and B were significantly $(p<0.05)$ less than the control site $C$. The $\mathrm{pH}$ of soil sample obtained from site $A$ was significantly higher relative to that of sites B and C. Similarly, the level of magnesium in the soil sample obtained from site $A$ was significantly higher than that of sites B and C.

The concentration of selected toxic metals in sampled soils obtained from the studied sites is presented in Table 2. Levels of $\mathrm{Fe}, \mathrm{Cu}, \mathrm{Zn}, \mathrm{Pb}$, and $\mathrm{Mn}$ in soil samples obtained from sites A and B were significantly $(p<0.05)$ higher than that of the control site $C$. In contrast, the levels of $\mathrm{Cu}, \mathrm{Fe}$, and $\mathrm{Zn}$ in soil samples obtained from sites $\mathrm{A}$
Table 1 Physicochemical parameters of sampled soils from Challawa and Kura village

\begin{tabular}{lrrrl}
\hline Parameter & Site A & Site B & Site C & $\begin{array}{l}\text { Permis- } \\
\text { sible limit } \\
{[54]}\end{array}$ \\
\hline $\mathrm{pH}$ & $8.57 \pm 0.33^{\mathrm{a}}$ & $7.77 \pm 0.33^{\mathrm{b}}$ & $7.47 \pm 0.33^{\mathrm{b}}$ & $6.0-9.0$ \\
Sulfate (mg/L) & $1.25 \pm 0.13^{\mathrm{a}}$ & $1.66 \pm 0.00^{\mathrm{b}}$ & $3.94 \pm 0.05^{\mathrm{c}}$ & 500 \\
Nitrate (mg/L) & $9.26 \pm 0.00^{\mathrm{a}}$ & $7.27 \pm 0.00^{\mathrm{b}}$ & $4.33 \pm 0.02^{\mathrm{c}}$ & 40 \\
Phosphate (mg/L) & $0.79 \pm 0.07^{\mathrm{a}}$ & $0.53 \pm 0.04^{\mathrm{b}}$ & $0.39 \pm 0.10^{\mathrm{c}}$ & 3.5 \\
Magnesium (mg/L) & $7.23 \pm 0.13^{\mathrm{a}}$ & $5.56 \pm 0.19^{\mathrm{b}}$ & $5.32 \pm 0.12^{\mathrm{b}}$ & - \\
Iron (mg/L) & $5.96 \pm 0.30^{\mathrm{a}}$ & $4.94 \pm 0.11^{\mathrm{b}}$ & $3.87 \pm 0.20^{\mathrm{c}}$ & - \\
Chloride (mg/L) & $12.67 \pm 0.05^{\mathrm{a}}$ & $12.61 \pm 0.15^{\mathrm{a}}$ & $10.55 \pm 0.52^{\mathrm{b}}$ & 350 \\
\hline
\end{tabular}

Values across the row with different letters differ significantly $(p<0.05)$

$A$ : Challawa effluent site $A$; $B$ : Challawa effluent site $B ; C$ : Kura village sample site NESREA, National Environmental Standards and Regulations Enforcement Agency [54] 
Table 2 Levels of selected heavy metal in sampled soils from Challawa and Kura village

\begin{tabular}{lllll}
\hline Parameter $(\mathrm{mg} / \mathrm{kg})$ & Site A & Site B & Site C & $\begin{array}{l}\text { Threshold limit } \\
\text { SPS:refid::bib50[49] }\end{array}$ \\
\hline Iron & $5.96 \pm 0.30^{\mathrm{a}}$ & $4.94 \pm 0.10^{\mathrm{b}}$ & $3.87 \pm 0.20^{\mathrm{c}}$ & - \\
Copper & $5.03 \pm 0.01^{\mathrm{a}}$ & $4.38 \pm 0.01^{\mathrm{b}}$ & $2.31 \pm 0.03^{\mathrm{c}}$ & 100 \\
Zinc & $1.29 \pm 0.07^{\mathrm{a}}$ & $1.16 \pm 0.02^{\mathrm{b}}$ & $1.01 \pm 0.05^{\mathrm{c}}$ & 200 \\
Lead & $3.10 \pm 0.07^{\mathrm{a}}$ & $3.00 \pm 0.01^{\mathrm{a}}$ & $1.00 \pm 0.03^{\mathrm{b}}$ & 60 \\
Cobalt & $1.00 \pm 0.02^{\mathrm{a}}$ & $1.10 \pm 0.01^{\mathrm{b}}$ & $0.98 \pm 0.03^{\mathrm{a}}$ & 20 \\
Manganese & $0.99 \pm 0.02^{\mathrm{a}}$ & $1.13 \pm 0.09^{\mathrm{a}}$ & $0.88 \pm 0.01^{\mathrm{c}}$ & - \\
Chromium & ND & ND & ND & 100 \\
\hline
\end{tabular}

Values across the rows with different letters differ significantly $(p<0.05)$

A: Challawa effluent site A; B: Challawa effluent site B; $C$ : Kura village sample site

Ministry of the Environment, Finland, [50]
Table 3 Concentrations of heavy metals in the roots and shoots of Azadirachta indica in Challawa and Kura village sites

\begin{tabular}{|c|c|c|c|}
\hline Metal (mg/Kg) & Site & Root & Shoot \\
\hline \multirow[t]{3}{*}{$\mathrm{Fe}$} & $A$ & $5.42 \pm 0.54^{\mathrm{a}}$ & $0.19 \pm 0.07^{\mathrm{a}}$ \\
\hline & B & $4.97 \pm 0.12^{b}$ & $0.17 \pm 0.04^{a}$ \\
\hline & $\mathrm{C}$ & $4.87 \pm 0.23^{b}$ & $0.10 \pm 0.01^{b}$ \\
\hline \multirow[t]{3}{*}{$\mathrm{Cu}$} & A & $0.74 \pm 0.54^{\mathrm{a}}$ & $0.70 \pm 0.03^{\mathrm{a}}$ \\
\hline & B & $0.46 \pm 0.00^{b}$ & $0.17 \pm 0.00^{\mathrm{a}}$ \\
\hline & C & $0.44 \pm 0.00^{b}$ & $0.08 \pm 0.01^{b}$ \\
\hline \multirow[t]{3}{*}{$\mathrm{Zn}$} & $A$ & $0.22 \pm 0.00^{\mathrm{a}}$ & $0.19 \pm 0.05^{\mathrm{a}}$ \\
\hline & B & $0.17 \pm 0.02^{b}$ & $0.18 \pm 0.21^{\mathrm{a}}$ \\
\hline & C & $0.17 \pm 0.02^{b}$ & $0.15 \pm 0.02^{b}$ \\
\hline \multirow[t]{3}{*}{ Co } & $A$ & $0.40 \pm 0.03^{\mathrm{a}}$ & ND \\
\hline & B & $0.21 \pm 0.00^{b}$ & ND \\
\hline & $\mathrm{C}$ & $0.15 \pm 0.05^{c}$ & ND \\
\hline \multirow[t]{3}{*}{$\mathrm{Pb}$} & $A$ & $0.41 \pm 0.00^{\mathrm{a}}$ & $0.71 \pm 0.05^{a}$ \\
\hline & B & $0.43 \pm 0.00^{b}$ & $0.80 \pm 0.06^{b}$ \\
\hline & C & $0.81 \pm 0.00^{c}$ & $0.82 \pm 0.00^{c}$ \\
\hline \multirow[t]{3}{*}{$\mathrm{Cr}$} & $A$ & ND & ND \\
\hline & B & ND & ND \\
\hline & $\mathrm{C}$ & $0.40 \pm 0.00$ & $0.60 \pm 0.00$ \\
\hline \multirow[t]{3}{*}{$\mathrm{Mn}$} & $A$ & $0.30 \pm 0.07^{\mathrm{a}}$ & $0.26 \pm 0.01^{a}$ \\
\hline & B & $0.19 \pm 0.02^{b}$ & $0.12 \pm 0.00^{b}$ \\
\hline & $\mathrm{C}$ & $0.12 \pm 0.07^{c}$ & $0.10 \pm 0.00^{c}$ \\
\hline
\end{tabular}

Values across the rows with different letters differ significantly $(p<0.05)$

A: Challawa effluent site A; B: Challawa effluent site B; C: Kura village sample site

were significantly $(p<0.05)$ higher than site B. However, the concentrations of $\mathrm{Pb}$ and $\mathrm{Mn}$ in soil sample obtained from site A were not significantly different from that of site B. There was no significant $(p<0.05)$ difference in cobalt level of soil sample obtained from site $A$ and that of the control soil sample. The level of cobalt in the soil sample obtained from site $B$ however was significantly higher in comparison with that of the control site $C$.
The amount of $\mathrm{Fe}, \mathrm{Cu}$, and $\mathrm{Zn}$ in the roots of $A$. indica tree obtained from site A were significantly $(p<0.05)$ higher than the control location. However, the amounts of $\mathrm{Fe}, \mathrm{Cu}$ and $\mathrm{Zn}$ in the root of $A$. indica plant obtained from site $B$ and that of the control location were not significantly different (Table 3 ). The amounts of $\mathrm{Pb}$ in the roots of $A$. indica plant obtained from sites $A$ and $B$ were significantly lower than the control location. In contrast, the concentrations of $\mathrm{Co}$ and $\mathrm{Mn}$ in the roots of plant obtained from sites $A$ and $B$ were significantly higher relative to the control location. The levels of $\mathrm{As}$ and $\mathrm{Ni}$ were below detectable limit in the roots of $A$. indica plants obtained from all the three locations. Although, $\mathrm{Cr}$ was below detection level in the roots of $A$. indica plants obtained from sites $A$ and $B$, its level in the root of $A$. indica plant obtained from the control location was measurable.

The levels of $\mathrm{Fe}, \mathrm{Cu}, \mathrm{Zn}$ and $\mathrm{Mn}$ in the shoots of $A$. indica plant obtained from sites $A$ and $B$ were significantly higher than that of the control location, but $\mathrm{Pb}$ concentrations in the shoots of $A$. indica plant obtained from sites $A$ and $B$ were significantly lower to what was obtained from the control location. The levels of $\mathrm{Co}, \mathrm{Ni}$ and $\mathrm{As}$ in the shoot of A. indica plant obtained from all of the sampled locations were below detection limit. Similarly, the concentrations of $\mathrm{Cr}$ in the shoot of $A$. indica plant obtained from sites $\mathrm{A}$ and $B$ were below detection limit, although its level in the shoot of $A$. indica plant obtained from the control location was measurable.

The TF, BCF, BAC and CF for $A$. indica obtained from the sampled sites are shown in Table 4. Azadirachta indica plant collected from all of the studied locations had TF $<1$ for most of the selected heavy metals studied ( $\mathrm{Fe}, \mathrm{Cu}, \mathrm{Co}$ and $\mathrm{Mn}$ ), except for $\mathrm{Pb}$ and $\mathrm{Zn}$ (site $\mathrm{C}$ ) where it showed $\mathrm{TF}>1$. Similarly, A. indica plant had $\mathrm{BCF}<1$ for $\mathrm{Cu}, \mathrm{Zn}$, $\mathrm{Co}, \mathrm{Pb}$ and $\mathrm{Mn}$ from the three studied locations, while it showed BCF $>1$ for Fe. The BAC and CF values for $A$. 
Table 4 Phytoremediation quotients (TC, BCT, BAT and CF) of Azadirachta indica tree for studied metals in sampled soils from Challawa and Kura village

\begin{tabular}{llllll}
\hline Metal $(\mathrm{mg} / \mathrm{kg})$ & Site & TF & BCF & BAC & CF \\
\hline Fe & A & 0.035 & 0.909 & 0.032 & - \\
& B & 0.034 & 1.006 & 0.034 & - \\
& C & 0.021 & 1.258 & 0.026 & - \\
$\mathrm{Cu}$ & A & 0.946 & 0.147 & 0.139 & 0.050 \\
& B & 0.370 & 0.105 & 0.039 & 0.044 \\
& C & 0.182 & 0.190 & 0.035 & 0.231 \\
Zn & A & 0.864 & 0.170 & 0.147 & 0.007 \\
& B & 1.059 & 0.146 & 0.155 & 0.006 \\
& C & 0.882 & 0.169 & 0.149 & 0.005 \\
Co & A & - & 0.400 & - & 0.050 \\
& B & - & 0.191 & - & 0.055 \\
& C & - & 0.153 & - & 0.049 \\
Pb & A & 1.732 & 0.132 & 0.229 & 0.051 \\
& B & 1.860 & 0.143 & 0.267 & 0.050 \\
& C & 1.012 & 0.810 & 0.820 & 0.049 \\
Mn & A & 0.867 & 0.303 & 0.263 & - \\
& B & 0.632 & 0.168 & 0.106 & - \\
& C & 0.833 & 0.136 & 0.114 & - \\
\hline
\end{tabular}

A: Challawa effluent site A; B: Challawa effluent site B; C: Kura village sample site

TF translocation factor, $B C F$ biological concentration factor, $B A C$ biological accumulation coefficient

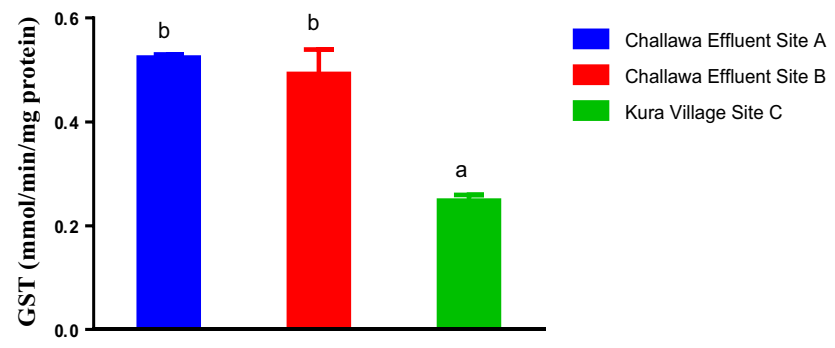

Fig. 2 Specific activity of glutathione-S-transferase in supernatants of $L$. terrestris from Challawa and Kura village soils. Values are expressed as means $\pm S D$. Bars with different letters differ significantly $(p<0.05)$

indica plant in this study were found to be $<1$ for all of the selected heavy metals.

Figure 2 depicts the level of glutathione-S-transferase (GST) in supernatants of $L$. terrestris from the sampled locations. The activity of GST in the supernatants of $L$. terrestris obtained from sites A and B were significantly $(p<0.05)$ higher than the control location. GST levels in supernatants of $L$. terrestris obtained from sites $A, B$ and the control site were not significantly different.

The activity of catalase (CAT) in the supernatants of $L$. terrestris obtained from the studied locations is presented

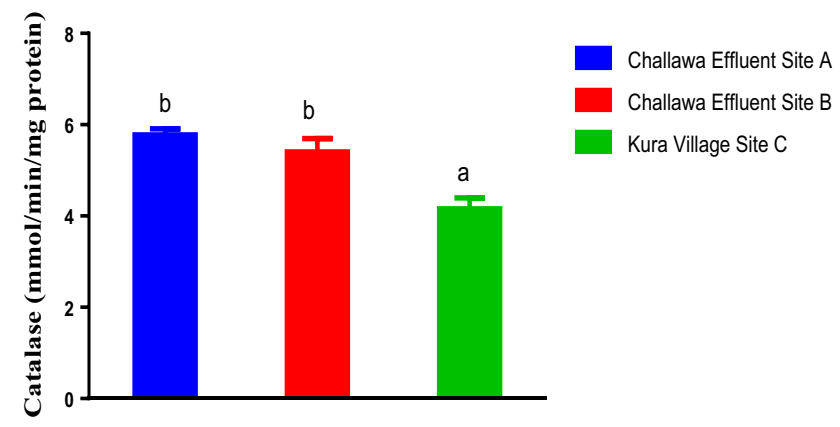

Fig. 3 Specific activity of catalase in supernatants of $L$. terrestris from Challawa and Kura village soils. Values are expressed as mean \pm SD. Bars with different letter differ significantly $(p<0.05)$

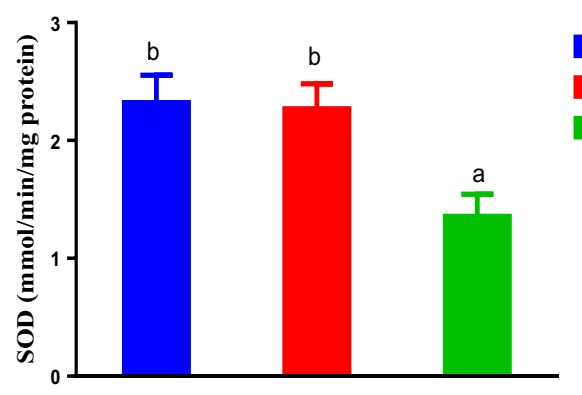

Challawa Effluent Site A
Challawa Effluent Site B Kura Village Site C

Fig. 4 Specific activity of superoxide dismutase in supernatants of $L$. terrestris from Challawa and Kura village soils. Values are expressed as mean $\pm S D$. Bars with different letters differ significantly $(p<0.05)$

in Fig. 3. Catalase activity in the supernatants of $L$. terrestris obtained from sites A and B were significantly $(p<0.05)$ higher than the control site. However, activities of CAT in supernatants of $L$. terrestris obtained from sites $A$ and $B$ were not significantly different.

Figure 4 depicts superoxide dismutase (SOD) activity in the supernatants of $L$. terrestris obtained from the studied locations. The activity SOD in the supernatants of $L$. terrestris obtained from sites A and B were significantly $(p<0.05)$ higher than the control location. The activity of SOD in the supernatants of $L$. terrestris obtained from site $A$ and that of site $B$ were not significantly different.

The activity of acetylcholinesterase (AChE) in supernatants of $L$. terrestris obtained from the sampled locations is presented in Fig. 5. Acetylcholinesterase (AChE) activities in supernatants of $L$. terrestris obtained from sites $A$ and B were significantly $(p<0.05)$ lower when compared to that of the control site. There was no significant difference found between AChE activities in the supernatants of $L$. terrestris obtained from site $A$ and $B$.

The level of reduced glutathione (GSH) in supernatants of $L$. terrestris obtained from the studied locations is presented in Fig. 6. The GSH level in the supernatants of $L$. 


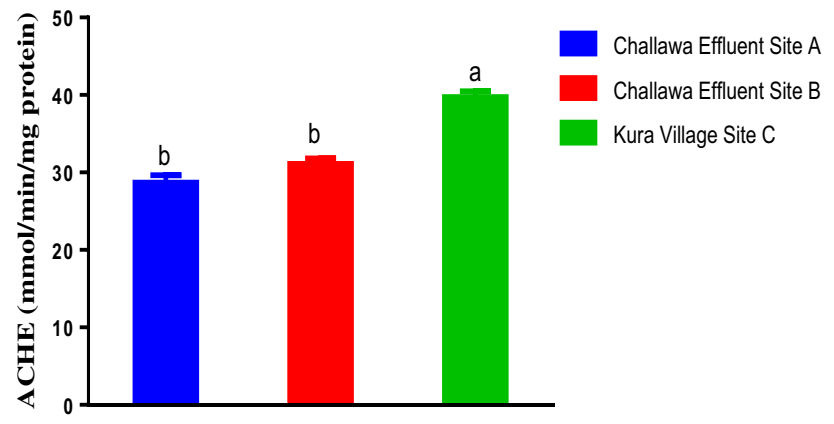

Fig. 5 Specific activity of acetylcholinesterase in supernatants of $L$. terrestris from Challawa and Kura village soils. Values are expressed as mean $\pm S D$. Bars with different superscript letters differ significantly $(p<0.05)$

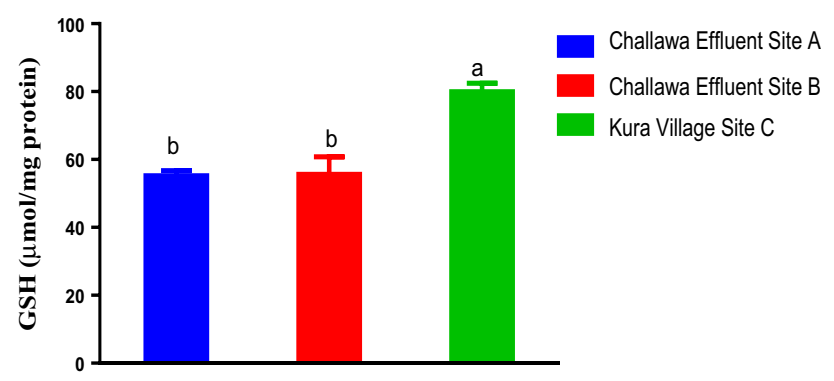

Fig. 6 Levels of reduced glutathione in supernatants of $L$. terrestris obtained from Challawa and Kura village soils. Values are expressed as mean \pm SD. Bars with different letters differ significantly $(p<0.05)$

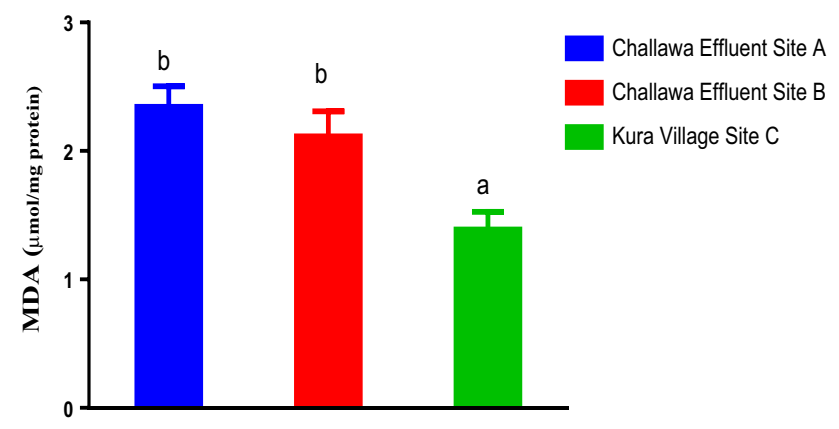

Fig. 7 Concentration of malondialdehyde in supernatants of L. terrestris from Challawa and Kura village soils. Values are expressed as mean \pm SD. Bars with different letters differ significantly $(p<0.05)$

terrestris obtained from sites A and B were significantly $(p<0.05)$ higher in comparison with the control location. The levels of GSH in the supernatant of $L$. terrestris obtained from sites $A$ and that of site B were not significantly different.
Figure 7 depicts the level of malondialdehyde (MDA) in supernatants of $L$. terrestris obtained from the sampled locations. The amount of MDA in the supernatants of $L$. terrestris obtained from sites $A$ and $B$ were not significantly different; however, they were both significantly $(p<0.05)$ higher when compared to that of control location.

\section{Discussion}

Healthy soil needs to have a good structure, adequate organic material and be a place of abode to different kinds of organisms [17]. A soil considered to be healthy must possess several physicochemical and biological properties which permit it to perform its essential functions. This can be achieved in a natural environment by a soil attaining equilibrium with its surroundings, or in an environment managed by human intervention to improve the health of the soil [71]. The health of agricultural soils is linked to human health, since poor soils produce crops with reduced nutritional value. In addition, healthy soils also decrease erosion and help improve water and air quality [16].

In this study, all of the physicochemical parameters analyzed in soils obtained from the sampled locations were below the national standard permissible limit for effluent discharge into surface water [28]. The transportability, solubility and availability of toxic metals in the soil are impacted by $\mathrm{pH}$ of the soil and their transport decreases with increasing $\mathrm{pH}$ value, due to the precipitation of hydroxides and carbonates, consequently forming insoluble organic complexes $[12,64]$. The $\mathrm{pH}$ of the soil samples obtained from the studied locations ranged from 7.47 to 8.57 , which may have resulted in reduced removal or translocation of heavy metals by $A$. indica at these locations due to the moderately alkaline nature of soils. Although, phosphate level in the sampled locations were below the allowed limit, addition of phosphate to soils increases translocation of metals in soils. Mechanisms such as adsorption, dissolution/precipitation reactions, calcium substitution by metals during crystallization, and ion exchange processes facilitates translocation [51]. Therefore, elevated level of phosphate may enhance phytoremediation by promoting adequate levels of heavy metals that can be mop up by plant.

The results of heavy metal analysis in this study showed that levels of selected heavy metals in the soils obtained from the sampled locations were higher than the control location which is an indication of increasing heavy metal contamination from anthropogenic activities. However, the amount of these toxic metals in the soils obtained from sampled locations were below 
the threshold limit approved by Finland's Ministry of the Environment [50]. The mean concentrations of the heavy metals in the soils across all studied sites are in the decreasing order of $\mathrm{Fe}>\mathrm{Cu}>\mathrm{Pb}>\mathrm{Zn}>\mathrm{Co}>\mathrm{Mn}$. Heavy metal contamination alters the biochemical properties of the soil including changes in the composition, size as well as the microbial community of the soil [73].

Climatic conditions, $\mathrm{pH}$, types and age of plant, type and form of the metals are the major factors responsible for bioaccumulation of metals in plants [47]. In this present study, most of the selected heavy metals except $\mathrm{Pb}$ build up in the roots than in the shoots of $A$. indica plant. The reduced translocation of heavy metals into the shoots of the plant may be as a result of defense mechanisms adopted by plants to prevent bioaccumulation of heavy metals beyond the toxic threshold level $[34,66]$. These mechanisms include change in membrane permeability, prevention of toxic metal ion transport across membrane, complexation of metals to ligands, increased exudation of compounds that chelate metal, stimulation of efflux pumping, and alteration in binding capacity of metalcell wall $[34,53,72]$. The defense strategies of plants for heavy metal avoidance and tolerance is dependent on the nature and concentration of metal, species, organ and stage of development of the plant [53]. Bioaccumulation of heavy metals in the root of $A$. indica tree from all of the studied locations followed decreasing order of $\mathrm{Fe}>\mathrm{Cu}>\mathrm{Pb}>\mathrm{Co}>\mathrm{Mn}>\mathrm{Zn}$ and were found to be within the allowed limit for heavy metals in the shoot [39].

Translocation factor shows the ability of plant species to transfer piled up metal from their roots to their shoot [43]. TF $>1$ indicates efficient transfer from the roots to the shoot [11]. Azadirachta indica had TF $>1$ for $\mathrm{Pb}$ and $\mathrm{Zn}$ in this study which implies that the plant can be used for phytoremediation $[30,46]$. In contrast, $A$. indica was found to have $\mathrm{TF}<1$ for other metals, $\mathrm{Fe}, \mathrm{Cu}, \mathrm{Co}$ and $\mathrm{Mn}$, which is an indication of inefficient root to shoot transfer of these metals in the plant. Therefore, $A$. indica plant restricted the transfer of these metals $\mathrm{Fe}, \mathrm{Cu}, \mathrm{Co}$ and $\mathrm{Mn}$ ) from the root to its shoot, thereby making it a good candidate for phytostabilization in the soil [13]. Phytostabilization is a technique that is employed to decrease the translocation and bioaccessibility of contaminants in the habitat, thereby preventing it from gaining access to the food chain or migration to groundwater [25]. Heavy metals in the soil may be immobilized by certain plants through complexation, precipitation, assimilation by roots or by reducing the valency of the metal in the rhizosphere $[13,74]$. Plants with high BCF and low TF have been suggested to be useful for phytostabilization of contaminant in the soil [48]. In this study, A. indica plant had $\mathrm{BCF}>1$ and $\mathrm{TF}<1$ for Fe indicating that the plant retained $\mathrm{Fe}$ in its root and reduced its movement from the root to shoot [20]. These observations indicate the suitability of $A$. indica for phytostabilization of $\mathrm{Fe}$, $\mathrm{Cu}, \mathrm{Co}$ and $\mathrm{Mn}$. BAC measures the potential of a type of plant to accumulate metals from the soil into its tissues [44]. Plant species that have BAC $>1$ and TF $>1$ can be categorized as hyperaccumulators and are the most suitable for phytoextraction of heavy metal contaminants [74]. Azadirachta indica showed BAC value $<1$ for all of the metal studied which implies that the plant was inefficient in accumulating these metals in its shoot. This is in contrary to the work of Abdullahi et al. [1] that reported $\mathrm{BAC}$ values $>1$ for $\mathrm{Cd}, \mathrm{Cu}, \mathrm{Fe}, \mathrm{Mn}$ and $\mathrm{Pb}$ in the tissues of $A$. indica plant. Contamination factor is the ratio of the concentration of metal in the study samples to the baseline concentration. The CF values of all the metals evaluated in this study is less than 1 , this indicates that the level of contamination in the soil is very low. This might be due to efficiency of $A$. indica in extracting the heavy metals from the soil [61].

Abnormal ROS production and depletion of major cellular antioxidants induced directly or indirectly by exposure to transition metals with redox and non-redox mediators can cause oxidative damage of biomolecules, this is a well-known mechanisms of metal-stimulated toxicity $[26,60]$. Antioxidant defense system including reduced glutathione (GSH), superoxide dismutases (SOD), glutathione peroxidase (GSPx) and catalase counteracts the effect of ROS in living organisms [15]. Fluctuations in the levels of antioxidant enzymes and that of other antioxidant molecules such as GSH have been used for monitoring oxidative stress [68]. Activities of GST, CAT, and SOD in the supernatants of $L$. terrestris obtained from the two contaminated locations were elevated. The significant increase in these antioxidant enzymes could be a response to increased production ROS caused by the presence of toxic metal contaminants in soil $[15,75]$. Arise et al. [10] also observed elevated activities of these antioxidant enzymes in the supernatant of earthworms obtained from soil site contaminated by oil spills. Superoxide dismutases are considered to play pivotal antioxidant roles as it catalyzes superoxide anion dismutation to $\mathrm{H}_{2} \mathrm{O}_{2}$ and subsequently to water and oxygen by catalase, thereby preventing the accumulation of $\mathrm{H}_{2} \mathrm{O}_{2}$ in the cells. The superoxide dismutase-catalase system provides the front line of antioxidant mechanism of defense against reactive oxygen species [75]. The significant increase in MDA levels in the supernatants of $L$. terrestris obtained from the two contaminated locations is an indication of lipid peroxidation in the tissues of the organism. This might be caused by heavy metals in the soils from these polluted locations $[42,58]$. The depletion of GSH in the supernatants of $L$. terrestris obtained from the contaminated locations may be due to elevated level of ROS induced by toxic metals 
in these sampled soils [35]. Glutathione protects the cells against heavy metal induced oxidative stress [26]. Biosynthesis of GSH increases when the cells are acutely exposed to reactive oxygen species. However, when there is a sustained oxidative stress from chronic exposure to oxidative agents, GSH will be depleted because its synthesis cannot effectively cope with the increased production of ROS [35].

Acetylcholinesterase (AChE) is important for catalyzing the conversion of acetylcholine, a neurotransmitter, into choline and acetic acid, a reaction necessary for the termination of nerve impulses and signaling between synapses thereby preventing acetylcholine dispersal and activation of nearby receptors [49]. Acetylcholinesterase is irreversibly inhibited by organophosphate and carbamate compounds found in pesticides leading to building up of acetylcholine, hyperstimulation of muscarinic and nicotinic receptors, and disrupted nerve transmission [19]. Inhibition of acetylcholinesterase has been used to analyze the implication of environmental pollutants on the nervous system. Reduced activity of AChE was noticed in the supernatants of $L$. terrestris obtained from the two contaminated locations in this present study. The significant decrease in AChE activities could be attributed to the inhibitory effect of the pollutants found in the soils [29]. Several studies have reported the inhibitory role of some metallic ions such as $\mathrm{Pb}^{2+}, \mathrm{Cd}^{2+}, \mathrm{Hg}^{2+}$ and $\mathrm{Cu}^{2+}$ on $\mathrm{AChE}$ activity in humans and other animals $[2,38,59]$.

\section{Conclusion}

This present study showed that $A$. indica with a TF $>1$ for $\mathrm{Pb}$ and $\mathrm{Zn}$ might be useful for phytoextraction and photostabilization of $\mathrm{Fe}, \mathrm{Cu}, \mathrm{Co}$ and $\mathrm{Mn}$ in contaminated soils due to its restrictive efficiency of root to shoot transfer of these metals leading to their accumulation in the roots. Also, biochemical alterations in L. terrestris may serve as sensitive bioindicators of soil contamination.

\section{Compliance with ethical standard}

Conflict of interest The authors declare that there is no conflict of interest regarding the publication of this paper.

Open Access This article is licensed under a Creative Commons Attribution 4.0 International License, which permits use, sharing, adaptation, distribution and reproduction in any medium or format, as long as you give appropriate credit to the original author(s) and the source, provide a link to the Creative Commons licence, and indicate if changes were made. The images or other third party material in this article are included in the article's Creative Commons licence, unless indicated otherwise in a credit line to the material. If material is not included in the article's Creative Commons licence and your intended use is not permitted by statutory regulation or exceeds the permitted use, you will need to obtain permission directly from the copyright holder. To view a copy of this licence, visit http://creativecommons .org/licenses/by/4.0/.

\section{References}

1. Abdullahi UAA, Audu K, Shuaibu L (2016) Phytoremediation of contaminated soils from Challawa industrial estate, KanoNigeria. Sci J Anal Chem 4(5):59-65

2. Ademuyiwa O, Ugbaja RN, Rotimi SO, Abam E, Okediran BS, Dosumu OA, Onunkwor BO (2007) Erythrocyte acetylcholinesterase activity as a surrogate indicator of lead-induced neurotoxicity in occupational lead exposure in Abeokuta, Nigeria. Environ Toxicol Pharmacol 24(2):183-188

3. Aksoy A, Demirezen D, Duman F (2005) Bioaccumulation, detection and analyses of heavy metal pollution in Sultan Marsh and its environment. Water Air Soil Pollut 164:241-255

4. Ali H, Khan E, Ilahi I (2019) Environmental chemistry and ecotoxicology of hazardous heavy metals: environmental persistence, toxicity, and bioaccumulation. J Chem 2019:14

5. Ali H, Khan E, Sajad MA (2013) Phytoremediation of heavy metals-concepts and applications. Chemosphere 91:869-881

6. Alzohairy MA (2016) Therapeutics Role of Azadirachta indica(Neem) and their active constituents in diseases prevention and treatment. Evid-Based Complement Altern Med 2016:11

7. Alvarez A, Saez JM, Davila Costa JS, Colin VL, Fuentes MS, Cuozzo SA, Benimeli CS, Polti MA, Amoroso MJ (2017) Actinobacteria: current research and perspectives for bioremediation of pesticides and heavy metals. Chemosphere 166:41-62

8. AOAC (2005) Official methods of analysis of the Association of Analytical Chemists International, 18th edn. AOAC International, Gaithersburg, MD

9. APHA (1998) Standard methods for the examination of water and wastewater, 20th edn. American Public Health Association, American Water Works Association and Water Environmental Federation, Washington DC.

10. Arise RO, Aboyewa JA, Osioma E (2015) Biochemical changes in Lumbricus terrestris and Phytoaccumulation of heavy metals from Ugberikoko petroleum flow station swamps, Delta State, Nigeria. Niger J Basic Appl Sci 23(2):141-155

11. Baker AJM, Brooks RR (1989) Terrestrial higher plants which hyperaccumulate metallic elements. A review of their distribution, ecology and phytochemistry. Biorecovery 1:81-126

12. Balkhair KS, Ashraf MA (2016) Field accumulation risks of heavy metals in soil and vegetable crop irrigated with sewage water in western region of Saudi Arabia. Saudi J Biol Sci 23:S32-S44

13. Barceló J, Poschenrieder C (2003) Phytoremediation: principles and perspectives. Contrib Sci 2:333-344

14. Bichi MH (2000) Surface water quality in the Kano Industrial Environment. In: Falola JA, Ahmed K, Liman MA, Maiwada A (eds) Issues in Land Administration and Development in Northern Nigeria, Proceedings of the National Workshop on Land Administration and Development in Northern Nigeria, Department of Geography Bayero University, Kano, pp 305-313.

15. Birben E, Sahiner UM, Sackesen C, Erzurum S, Kalayci O (2012) Oxidative stress and antioxidant defense. WAO J 5:9-19

16. Brevik EC, Sauer TJ (2015) The past, present, and future of soils and human health studies. Soil 1(1):35-46

17. Brevik EC (2009) Soil health and productivity. In: Verheye W (ed) Soils, plant growth and crop production. Encyclopedia of life 
support systems (EOLSS), developed under the Auspices of the UNESCO. EOLSS Publishers, Oxford

18. Buege JA, Aust SD (1978) Microsomal lipid peroxidation. Methods Enzymol 52:302-305

19. Colovic MB, Krstic DZ, Lazarevi-Pasti TD, Bondzic AM, Vasic VM (2013) Acetylcholinesterase inhibitors: pharmacology and toxicology. Curr Neuropharmacol 11:315-335

20. Cui S, Zhou O, Chao L (2007) Potential hyperaccumulation of Pb, $\mathrm{Zn}, \mathrm{Cu}$ and $\mathrm{Cd}$ in endurant plants distributed in an old smeltery, Northeast China. Environ Geol 51:1043-1048

21. DalCorso G, Fasani E, Manara A, Visioli G, Furini A (2019) Heavy metal pollutions: state of the art and innovation in phytoremediation. Int J Mol Sci 20:3412

22. El-Kady AA, Abdel-Wahhab MA (2018) Occurrence of trace metals in foodstuffs and their health impact. Trands Food Sci Technol 75:36-45

23. Ellman GL (1959) Tissue sulfhydryl groups. Arch Biochem Biophys $82: 70-77$

24. Ellman GL, Courtney KD, Andres V, Featherstone RM (1961) A new and rapid colorimetric determination of acetyl cholinesterase activity. Biochem Pharmacol 7:88-95

25. Erakhrumen AA (2007) Phytoremediation: an environmentally sound technology for pollution prevention, control and remediation in developing countries. Edu Res Rev 2(7):151-156

26. Ercal N, Gurer-Orhan H, Aykin-Burns N (2001) Toxic metals and oxidative stress part I: mechanisms involved in metal induced oxidative damage. Curr Top Med Chem 1:529-539

27. Fakayode SO (2005) Impact assessment of industrial effluent on water quality of the receiving Alaro River in Ibadan, Nigeria. AJEAMRAGEE 10:1-13

28. FEPA (1991) Guidelines and standards for environment pollution control in Nigeria. Federal environmental protection agency, Federal Republic of Nigeria

29. Gambi N, Pasteris A, Fabbri E (2007) Acetylcholinesterase activity in the earthworm Eisenia andrei at different conditions of carbaryl exposure. Comp Biochem Physiol, Part C 145:678-685

30. Ghosh M, Singh SP (2005) A review on phytoremediation of heavy metals and utilization of it's by products. Asian J Energy Environ 6(4):214-231

31. Girish K, Shankara BS (2008) Neem: a green treasure. Electron J Biol 4:102-111

32. Gornal AG, bardwil, G.S. and david, M.M. (1949) Determination of serum proteins by the mean of the biuret reactions. Biochemistry 177:751-766

33. Habig WH, Pabst MJ, Jacoby WB (1974) Glutathione-S-transferases, the first enzymatic step in mercapturic acid formation. J Biol Chem 249(22):321-336

34. Hall JL (2002) Cellular mechanisms for heavy metal detoxification and tolerance. J Exp Bot 53(366):1-11

35. Hultberg B, Andersson A, Isaksson A (2001) Interaction of metals and thiols in cell damage and glutathione distribution: potentiation of mercury toxicity by dithiothreitol. Tox 156:93-100

36. lyengar V, Nair P (2000) Global outlook on nutrition and the environment: meeting the challenges of the next millennium. Sci Total Environ 249:331-346

37. Jan AT, Ali A, Haq QMR (2011) Glutathione as an antioxidant in inorganic mercury induced nephrotoxicity. J Postgrad Med 57:72-77

38. Jebali J, Banni M, Guerbej H, Almeida EA, Bannaoui A, Boussetta $\mathrm{H}$ (2006) Effects of malathion and cadmium on acetylcholinesterase activity and metallothionein levels in the fish Seriola dumerilli. Fish Physiol Biochem 32(1):93-98

39. Kabata-Pendias A (2011) Trace elements in soils and plants, 4th edn. FL, CRC, Press, Taylor and Francis Group, Boca Raton

40. Kammenga JE, Dallinger R, Donker MH, Köhler HR, Simonsen V, Triebskorn R, Weeks JM (2000) Biomarkers in terrestrial invertebrates for ecotoxicological soil risks assessment. Rev Environ Contam Toxicol 164:93-147

41. Kaplan JH, Grooves J (1972) Liver and blood cell catalase activity in tumor-bearing mice. Can Res 32:1190-1194

42. Khessiba A, Hoarau P, Gnassia-Barelli M, Assia P, Romeo M (2001) Biochemical response of the mussel Mytilus galloprovinincialis from Bizerta (Tunisia) to chemical pollutant exposure. Arch Environ Contam Toxicol 40:222-229

43. Kumar A, Ahirwal J, Maiti SK, Das R (2015) An assessment of metal in fly ash and their translocation and bioaccumulation in perennial grasses growing at the reclaimed opencast mines. Int J Environ Res 9(3):1089-1096

44. Ladislas S, El-Muflfleh A, Gerente C, Chazarenc F, Andres Y, Bechet $B$ (2012) Potential of aquatic macrophytes as bioindicators of heavy metal pollution in urban stormwater runoff. Water Air Soil Pollut 223:877-888

45. Lanno R, Wells J, Conder J, Bradham K, Basta N (2004) The bioavailability of chemicals in soil for earthworms. Ecotoxicol Environ Saf 57:39-47

46. Lazaro JD, Kidd PS, Martinez CM (2006) Phytogeochemical study of the Tras-os-Montes region (NE Portugal): possible species for plant based soil remediation technologies. Sci Total Environ 354:265-277

47. Maiti SK, Jaiswal S (2008) Bioaccumulation and translocation of metals in the natural vegetation growing on fly ash lagoons: a field study from Santaldih thermal power plant, West Bengal, India. Environ Monit Assess 136:355-370

48. Malik RN, Husain SZ, Nazir I (2010) Heavy metal contamination and accumulation in soil and wild plant species from industrial area of Islamabad, Pakistan. Pak J Bot 42(1):291-301

49. McHardy SF, Wang HL, McCowen SV, Valdez MC (2017) Recent advances in acetylcholinesterase inhibitors and reactivators: an update on the patent literature (2012-2015). Expert Opin Ther Pat 27(4):455-476

50. MEF, Ministry of the Environment Finland (2007) Government decree on the assessment of soil contamination and remediation needs. 214/2007.

51. Mignardi S, Corami A, Ferrini V (2012) Immobilization of heavy metals in soil by phosphate treatment: a review. In: Hong-Bo S (ed) Metal contamination: sources, detection and environmental impact. Nova Science Publishers, Inc, New York, pp 43-79

52. Misra HP, Fridovich I (1972) The role of superoxide ion in the auto-oxidation of epinephrine and a simple essay for superoxide dismutase. J Biol Chem 247(10):3170-3175

53. Navari-Izzo F, Quartacci MF (2001) Phytoremediation of metals: tolerance mechanisms against oxidative stress. Minerva Biotecnologica 13(2):73

54. NESREA: National Environmental Standards and Regulations Enforcement Agency (2011) National environmental (surface and ground water quality control) regulations-effluent discharges, irrigation and reuse standards

55. Ogundiran MA, Fawole OO (2014) Assessment of the impacts of industrial effluent discharges on the water quality of Asa River, Ilorin, Nigeria. IOSR J Environ Sci, Toxicol Food Technol 8(7):80-98

56. Okereke JN, Ogidi OI, Obasi KO (2016) Environmental and health impact of industrial wastewater effluents in Nigeria: a review. Int J Adv Res Biol Sci 3(6)

57. Paz-Alberto AM, Sigua GC (2013) Phytoremediation: a green technology to remove environmental pollutants. Am J Clim Change 2:71-86

58. Rehman S, Chandra O, Abdulla M (1995) Evaluation of malondialdehyde as an index of lead damage in rat brain homogenates. Biometals 8:275-279

59. Richetti SK, Rosemberg DB, Ventura-Lima J, Monserrat JM, Bogo MR, Bonan CD (2011) Acetylcholinesterase activity and 
antioxidant capacity of zebrafifish brain is altered by heavy metal exposure. NeuroToxicology 32(2011):116-122

60. Romeo M, Giamberini LC, Amiard JC, Rainboe PS (2013) Ecological biomarkers, indicators of ecotoxicological efects. CRC Press, Taylor and Francis Group, Boca Raton, London, New York

61. Said I, Salman SA, Elnazer AA (2019) Multivariate statistics and contamination factor to identify trace elements pollution in soil around Gerga City, Egypt. Bull Natl Res Centre 43(1):43

62. Salah SA, Barrington SF (2006) Effect to soil fertility and transpiration rate on young wheat plants (Triticum aestivum) $\mathrm{Cd} / \mathrm{Zn}$ uptake and yield. Agric Water Manag 82:177-192

63. Sheoran V, Sheoran A, Poonia P (2011) Role of hyperaccumulators in phytoextraction of metals from contaminated mining locations: a review. Crit Rev Env Sci Technol 41:168-214

64. Smith SR, Giller KE (1992) Effective Rhizobium leguminosarum biovar Trifolii present in five soils contaminated with heavy metals from long-term applications of sewage sludge or metal mine spoil. Soil Biol Biochem 24(8):781-788

65. Tangahu BV, Abdullah SRS, Basri $\mathrm{H}$, Idris $\mathrm{M}$, Anuar N, Mukhlisin $M$ (2011) A review on heavy metals (As, $\mathrm{Pb}$, and $\mathrm{Hg}$ ) uptake by plants through phytoremediation. Int J Chem Eng 2011:31

66. Thakur S, Singh L, Wahid ZA, Siddiqui MF, Atnaw SK, Din MFM (2016) Plant-driven removal of heavy metals from soil: uptake, translocation, tolerance mechanism, challenges, and future perspectives. Environ Monit Assess 188:1-11

67. Ahmed TF, Sushil M, Krishna M (2012) Impact of dye industrial effluent on physicochemical characteristics of Kshipra River, Ujjain City, India. Int Res J Environ Sci 1(2):41-45
68. Valko M, Leibfritz D, Moncol J, Cronin MT, Mazur M, Telser J (2007) Free radicals and antioxidants in normal physiological functions and human diseases. Int J Biochem Cell Biol 39:44-84

69. Valko M, Morris H, Cronin MTD (2005) Metals, toxicity and oxidative stress. Curr Med Chem 12:1161-1208

70. Vasavi A, Usha R, Swamy PM (2010) Phytoremediation: an overview review. J Ind Pollut Control 26(1):83-88

71. Wolf B, Snyder GH (2003) Sustainable soils: the place of organic matter in sustaining soils and their productivity. Haworth Press, New York

72. Yang X, Feng Y, He Z, Stoffella PJ (2005) Molecular mechanisms of heavy metal hyperaccumulation and phytoremediation. J Trace Elem Med Biol 18(4):339-353

73. Yao H, Xu J, Huang C (2003) Substrate utilization pattern, biomass and activity of microbial communities in a sequence of heavy metal polluted paddy soils. Geoderma 115:139-148

74. Yoon J, Cao X, Zhou, and Ma, L.Q. (2006) Accumulation of Pb, $\mathrm{Cu}$ and $\mathrm{Zn}$ in native plants growing on a contaminated Florida location. Sci Total Environ 368:456-464

75. Young I, Woodside J (2001) Antioxidants in health and disease. J Clin Pathol 54:176-186

Publisher's Note Springer Nature remains neutral with regard to jurisdictional claims in published maps and institutional affiliations. 